\title{
Thermal Characterization of a New Bio-Based Insulation Material Containing Puffed Rice
}

\author{
Maatouk Khoukhi *D, Abeer Dar Saleh, Ahmed Hassan and Shaimaa Abdelbaqi \\ College of Engineering, United Arab Emirates University, Al Ain 15551, United Arab Emirates; \\ 201870084@uaeu.ac.ae (A.D.S.); Ahmed.Hassan@uaeu.ac.ae (A.H.); 200734406@uaeu.ac.ae (S.A.) \\ * Correspondence: mkhoukhi@uaeu.ac.ae
}

check for updates

Citation: Khoukhi, M.; Dar Saleh, A.; Hassan, A.; Abdelbaqi, S. Thermal Characterization of a New Bio-Based Insulation Material Containing Puffed Rice. Energies 2021, 14, 5700. https://doi.org/10.3390/en14185700

Academic Editors: Mark Bomberg and F. Pacheco Torgal

Received: 11 August 2021

Accepted: 7 September 2021

Published: 10 September 2021

Publisher's Note: MDPI stays neutral with regard to jurisdictional claims in published maps and institutional affiliations.

Copyright: (c) 2021 by the authors. Licensee MDPI, Basel, Switzerland. This article is an open access article distributed under the terms and conditions of the Creative Commons Attribution (CC BY) license (https:/ / creativecommons.org/licenses/by/ $4.0 /)$.

\begin{abstract}
Although many advanced insulation materials have been recently developed, very few are eco-friendly and their production requires a substantial amount of energy and complex manufacturing processes. To address this issue, a bio-based thermal insulation material was developed using short- and long-grained puffed rice. A set of experiments was subsequently carried out to identify the best rice type and the optimal range for the most influential parameters (sample amount, temperature, and moisture level). Our findings revealed that short-grained rice exhibited greater puffing ability and was thus adopted in further material optimization experiments. These assessments indicated that the most optimal thermal conductivity of the insulation material and the highest puffing ratio was attained at $12-15 \%$ moisture, $260-270{ }^{\circ} \mathrm{C}$ temperature, and $15-18 \mathrm{~g}$ sample weight. The thermal properties, including thermal conductivity and fire reaction, and thermal performance of samples obtained using these parameters were similar to those of common insulation materials.
\end{abstract}

Keywords: green material; building insulation; thermal conductivity; bio-based insulation; energy consumption

\section{Introduction}

In the construction sector, energy consumption is typically lowered by adopting effective insulation strategies. This is particularly important in residential buildings, where extensive amounts of energy are utilized daily for heating and cooling in order to ensure thermal comfort. Hence, applying effective insulation strategies has the potential to reduce energy expenditure, thus preserving natural resources such as petroleum and gas reserves used for power generation [1].

Owing to the continued increase in energy consumption and rapidly escalating climate change, the pressure to find sustainable alternatives to nonrenewable energy resources is growing [2]. According to the International Energy Agency (IEA) forecasts, by 2025, the energy consumption worldwide is expected to increase by $50 \%$ due to the significant increase in industrial and urban activities related to intensive economic development and a dramatic increase in population size [3-5]. To reduce the energy consumption in newly designed buildings, improving energy efficiency is essential and can be achieved by using systems that optimize energy utilization and dissipation [6].

The Middle East is characterized by long hot and humid summers that extend for more than six months. Due to such a harsh climate, AC systems are one of the biggest power consumers in this region and contribute up to $50 \%$ to the total energy consumption [7]. Using air-conditioning systems is very crucial to provide thermal comfort in buildings of the United Arab Emirates (UAE). These systems have the largest amount of energy consumption; for example, in Middle Eastern countries the energy consumption for space cooling in the residential sector is approximately $50 \%$ of the total energy consumption $[7,8]$. To mitigate this issue, more effective thermal insulation materials should be installed, especially in new buildings, to increase energy efficiency and decrease greenhouse gas emissions. 
Most insulating materials are human made (organic and inorganic). Several studies have investigated the thermo-physical properties of such materials; hence, increasing attention has been given to the ecological and environmental impacts and overall sustainability of construction materials [9].

Bio-based insulation materials are produced from renewable biological resources, such as lignocellulose, agricultural plant waste, and animal materials such as fur and wool [10]. Their high internal porosity provides a low bulk density and a low thermal conductivity [11]. These features enable bio-based insulation materials to fulfill their required needs without significant and often costly transformation [12]. However, the greatest advantage of these materials is their biological origin, and thus the potential to reduce the landfill waste due to their high biodegradability. However, owing to high moisture absorption, they tend to suffer from low mold resistance, reduced durability, and suboptimal fire reaction [13].

Many types of bio-based insulation materials are already available on the market and many more are still in the early experimental stages. Table 1 shows the physical performance parameters for the most common bio-based building insulation materials in their natural composite form [14-17]. The majority of the materials listed in Table 1 are not completely characterized, and many parameters such as specific heat, fire classification, and water resistance are lacking, but their thermal conductivity is always reported.

Table 1. Physical performance parameters for most bio-based insulation materials $[12,14,15,18]$.

\begin{tabular}{|c|c|c|c|c|c|c|}
\hline $\begin{array}{l}\text { Insulation } \\
\text { Materials }\end{array}$ & $\begin{array}{c}\text { Thermal } \\
\text { Conductivity } \\
\text { W/(mK) }\end{array}$ & $\begin{array}{l}\text { Density } \\
\mathrm{kg} / \mathrm{m}^{3}\end{array}$ & $\begin{array}{c}\text { Specific } \\
\text { Heat } \\
\mathrm{kJ} /(\mathrm{kgK})\end{array}$ & $\begin{array}{c}\text { Fire } \\
\text { Classification }\end{array}$ & $\begin{array}{c}\text { Water } \\
\text { Resistance }\end{array}$ & $\begin{array}{c}\text { Reference } \\
\text { Number }\end{array}$ \\
\hline Hemp & $0.038-0.060$ & $20-90$ & $1.6-1.7$ & $\mathrm{E}$ & $1.0-2.0$ & {$[14,15]$} \\
\hline Straw & $0.038-0.067$ & $50-150$ & 0.6 & NA & NA & {$[14,15]$} \\
\hline Flax & $0.038-0.075$ & 20-100 & $1.4-1.6$ & $\mathrm{E}$ & $1.0-2.0$ & [14] \\
\hline Wood fiber & $0.038-0.050$ & $50-270$ & $1.9-2.1$ & $\mathrm{E}$ & $1-5$ & [15] \\
\hline Cotton stalk & $0.0585-0.0815$ & $150-450$ & NA & NA & NA & {$[14,18]$} \\
\hline Corn cob & 0.10 & $171-334$ & NA & NA & NA & {$[12,18]$} \\
\hline sunflower & $0.0385-0.050$ & $36-152$ & NA & NA & NA & {$[12,18]$} \\
\hline palm date fibers & $0.0475-0.072$ & $187-389$ & NA & NA & NA & {$[14,18]$} \\
\hline Jute fiber & $0.038-0.055$ & $35-100$ & 2.3 & $\mathrm{E}$ & $1-2$ & [14] \\
\hline Kenaf & $0.034-0.043$ & $30-180$ & $1.6-1.7$ & D-E & $1.2-2.3$ & [14] \\
\hline Coir fiber & $0.040-0.045$ & $75-125$ & $1.3-1.6$ & $\mathrm{D}-\mathrm{Eb}$ & $5.0-30$ & [14] \\
\hline Cork & $0.037-0.050$ & $110-170$ & $1.5-1.7$ & $\mathrm{E}$ & $5-30$ & [14] \\
\hline Reeds & $0.045-0.056$ & $13-190$ & 1.2 & $\mathrm{E}$ & $1-2$ & {$[14,18]$} \\
\hline Bagasse & $0.046-0.055$ & $70-350$ & NA & NA & NA & {$[14,18]$} \\
\hline Cattail & $0.0438-0.0606$ & $200-400$ & NA & NA & NA & [18] \\
\hline Pineapple leaves & $0.035-0.042$ & $178-232$ & NA & NA & NA & [18] \\
\hline Durian peel & $0.064-0.185$ & 357-907 & NA & NA & NA & {$[14,18]$} \\
\hline Rice hulls & $0.0464-0.566$ & $154-168$ & NA & NA & NA & [18] \\
\hline Sansevieria fiber & 0.132 & 1410 & 1.52 & NA & NA & [18] \\
\hline
\end{tabular}

In the selection of insulation material, fire classification and water vapor resistance are always considered. However, in the early stages of investigation of bio-based insulation materials, these two properties are usually not reported, as indicated by the many missing values in Table 1. It is also evident that the fire classification of these materials is normally low while their water vapor resistance is very encouraging. 


\section{Materials and Methods}

\subsection{Material}

In 2011, the Food and Agriculture Organization of the United Nations launched a study to estimate the amount of food wasted at the global level. According to their findings, about one-third of all food had been wasted or lost worldwide in the preceding year. The resulting financial losses were estimated at USD one trillion, pointing to extensive inefficiencies in the food chain that need to be rectified [17]. Consequently, in the 2030 agenda for sustainable development, focus was given to efforts aimed at reducing the global food waste at both the consumer and market share level, with the goal of a 50\% reduction. Food waste harms the environment, including land, soil, energy, and water. Moreover, the wasted food that is deposited into landfills contributes considerably to greenhouse gas emissions, especially methane, which is 23 times more harmful and deadly than carbon dioxide [18]. A study done by the Swedish Institute for Food and Biotechnology on the amount of wasted food for low-, medium-, and high-income countries, showed that high-income countries were the greatest contributors to food waste [19].

In 2011, the UN Food and Agriculture Organization estimated the annual waste food carbon footprint at around 3.5 billion tons of $\mathrm{CO}_{2}$, which exceeds the $\mathrm{CO}_{2}$ output of all industrial countries except the US and China. In most Asian countries, rice is considered a staple grain, as it can be cheaply produced to meet the food demand of the rapidly growing population [20]. However, according to the analysis conducted by the UN, considerable quantities of rice are wasted each year, contributing to about 610 million tons of $\mathrm{CO}_{2}$. The UAE, despite being a developed country, is one of the highest per capita consumers of rice. Statistics released by the state of Dubai indicate that around 772 million $\mathrm{kg}$ of rice were imported to the UAE in 2014, and $40 \%$ of this amount is disposed yearly, even though rice can be reused in an environmentally friendly way. For example, rice can be separated from food waste collected from different sources (homes, hotels) and reused in non-food sectors. In particular, rice grains can be puffed by heating in a sealed chamber at high pressure to modify their properties, such as malleability. Rice has a smooth surface, high porosity between molecules, and high interfacial areas, making it ideal for use in insulation.

In this study, two types (long- and short-grained) of raw rice readily available in the UAE (Figure 1) were used to obtain the puffed rice samples utilized in the fabrication of a novel thermal insulation material for the construction market. Samples produced from both rice types were subjected to several tests in order to identify the most suitable raw material for use in insulation fabrication.
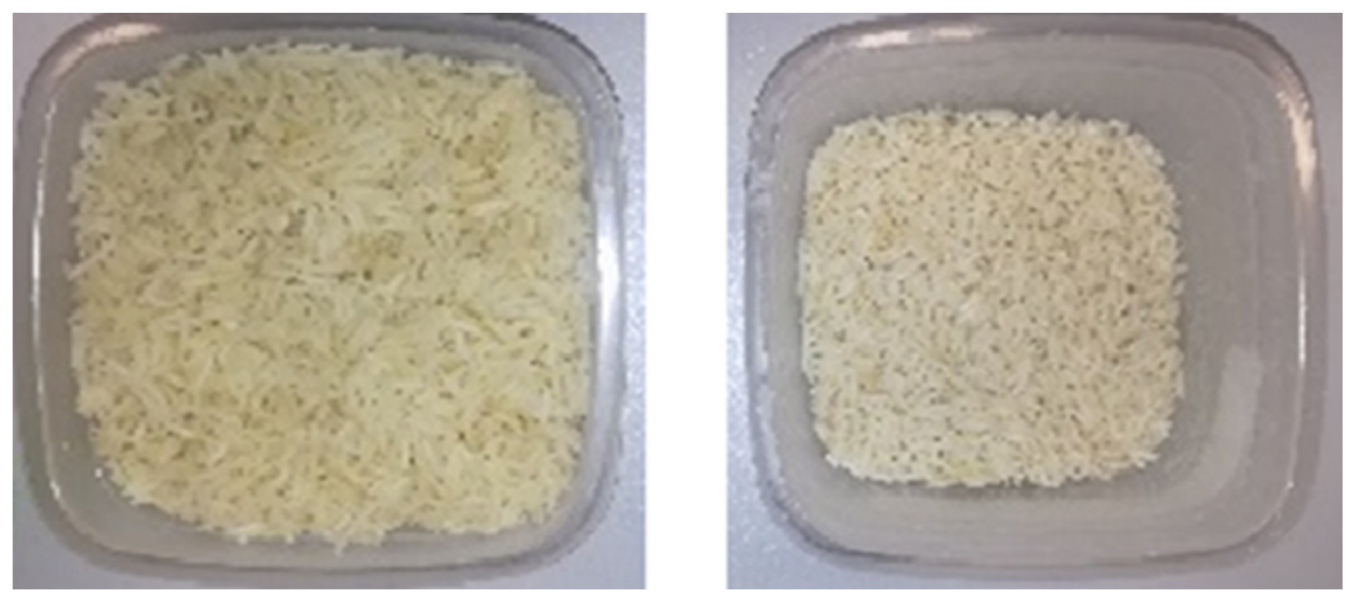

Figure 1. Local rice grains, long and short.

\subsection{Puffing Technique Methods}

In the food industry, expansion can be achieved through popping or puffing. The popping method is used to obtain popcorn from maize, while grains, which do not contain 
enough water to reach the explosive expansion, are puffed. The puffing method affects the porosity of the produced sample and can create large areas characterized by high porosity, which has a direct effect on the heat transmission within the material and decreases the overall thermal conductivity. Thus, as puffed rice was chosen to develop a new bioinsulation material in this study, we subjected it to extensive tests to ensure that it had the most optimal characteristics.

The scanning electron microscopy (SEM) images shown in Figure 2 indicate that during the puffing process, air bubbles form between cells causing the grains to expand without bursting [21]. The resulting rice cakes were subjected to the AACC rapeseed displacement method to determine the true and bulk volume of the puffed rice layers and thus the overall porosity. The true volume was obtained by compressing the sample until no pores remained, whereas the bulk volume was determined using a regular sample without compressing [22].

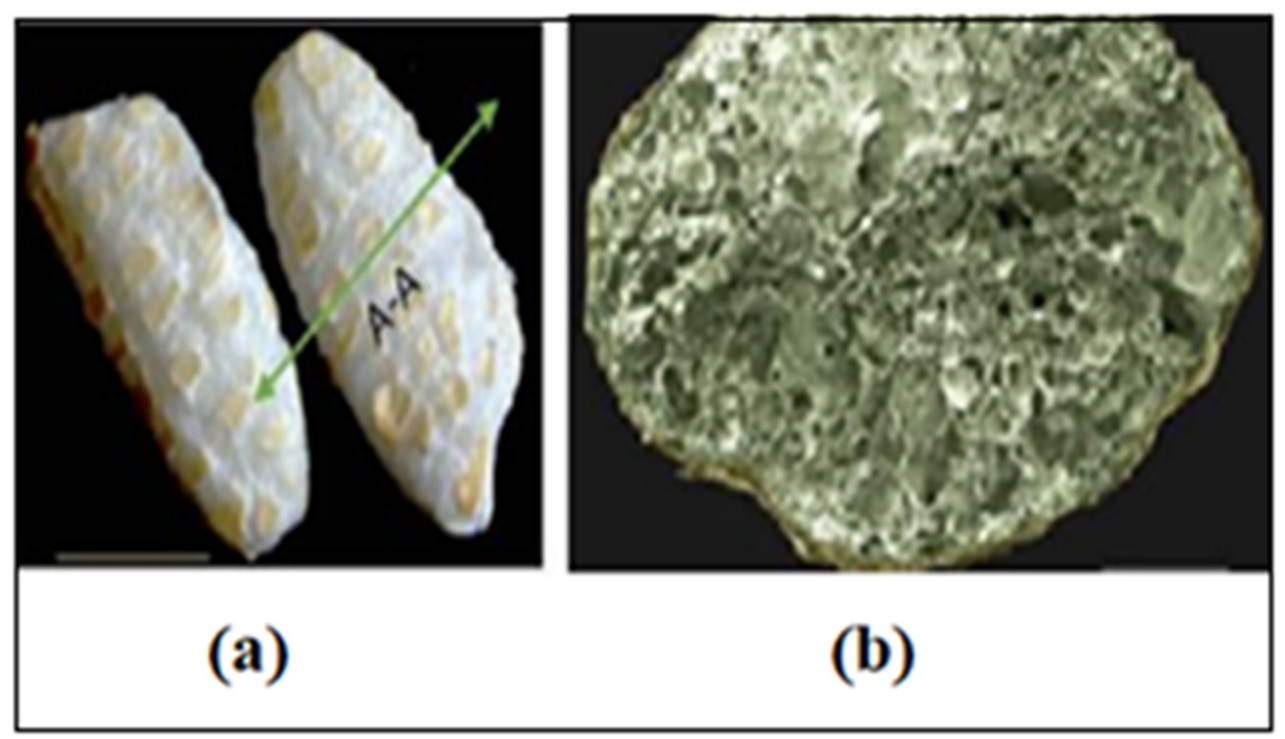

Figure 2. (a) SEM photograph of two puffed rice grains: Bar, $5 \mathrm{~mm}$. (b) SEM cross section of a puffed rice grain showing air cells and a compact grain surface [23].

\subsection{Fabrication of Insulation Material Sample}

Prior to puffing, raw rice was soaked in water for about $12 \mathrm{~h}$ to remove starch, as it prevents grain expansion. Next, the rice was dried by exposing it to room temperature for 12 to $24 \mathrm{~h}$, during which the moisture level was assessed using a moisture analyzer to ensure that the desired moisture percentage was achieved, as shown in Figure 3.

Once the required moisture level was attained, rice grains were exposed to high temperature $\left(250-270{ }^{\circ} \mathrm{C}\right)$ and 40 bar pressures. The apparatus used in the production of the bio-insulation samples had a small gear-shaped motor, driven by a protruding wheel, as well as a temperature and a pressure controller, as shown in Figure 4. The adjusted mold had a circular shape of $8 \mathrm{~cm}$ in diameter. 


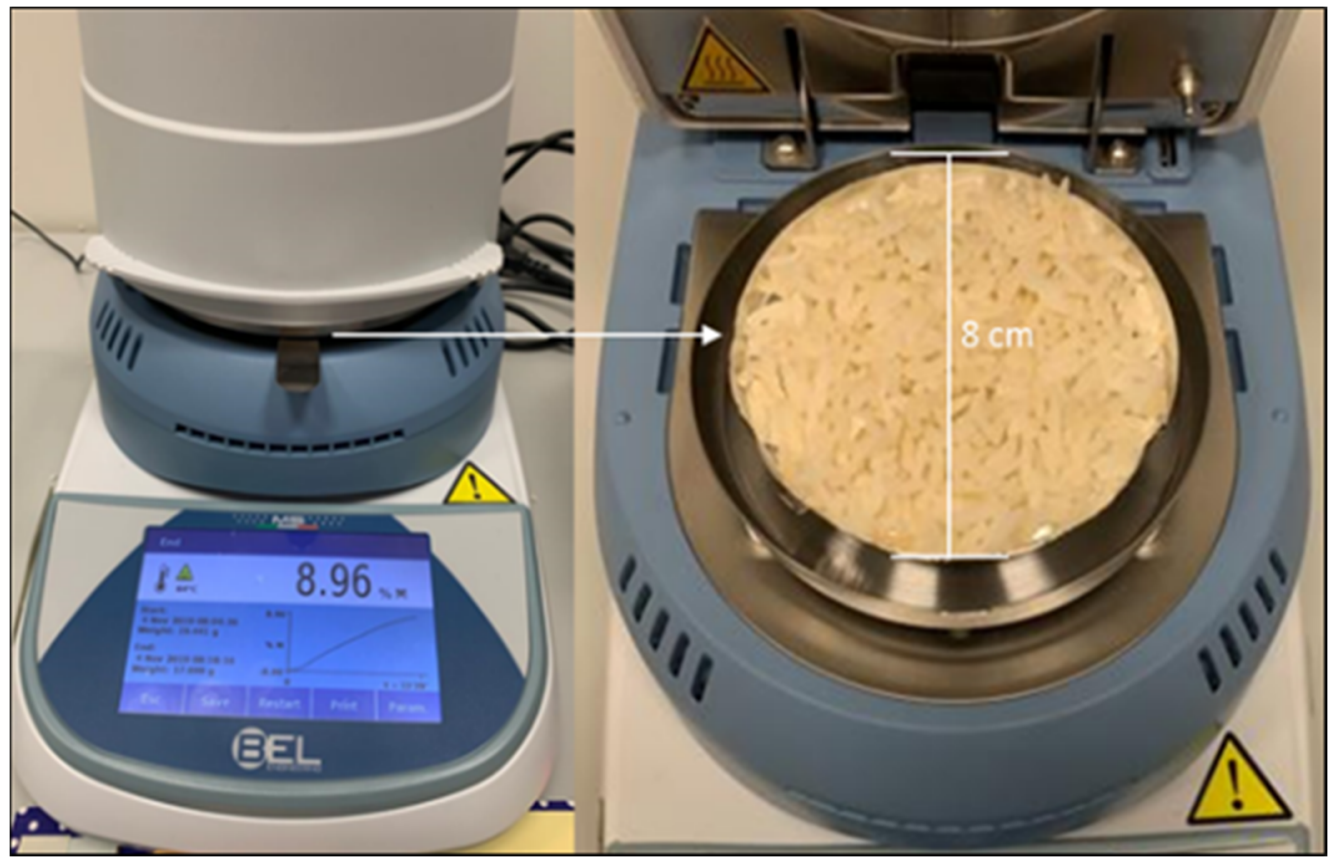

Figure 3. Moisture analyzer used to control the moisture level of the raw material.

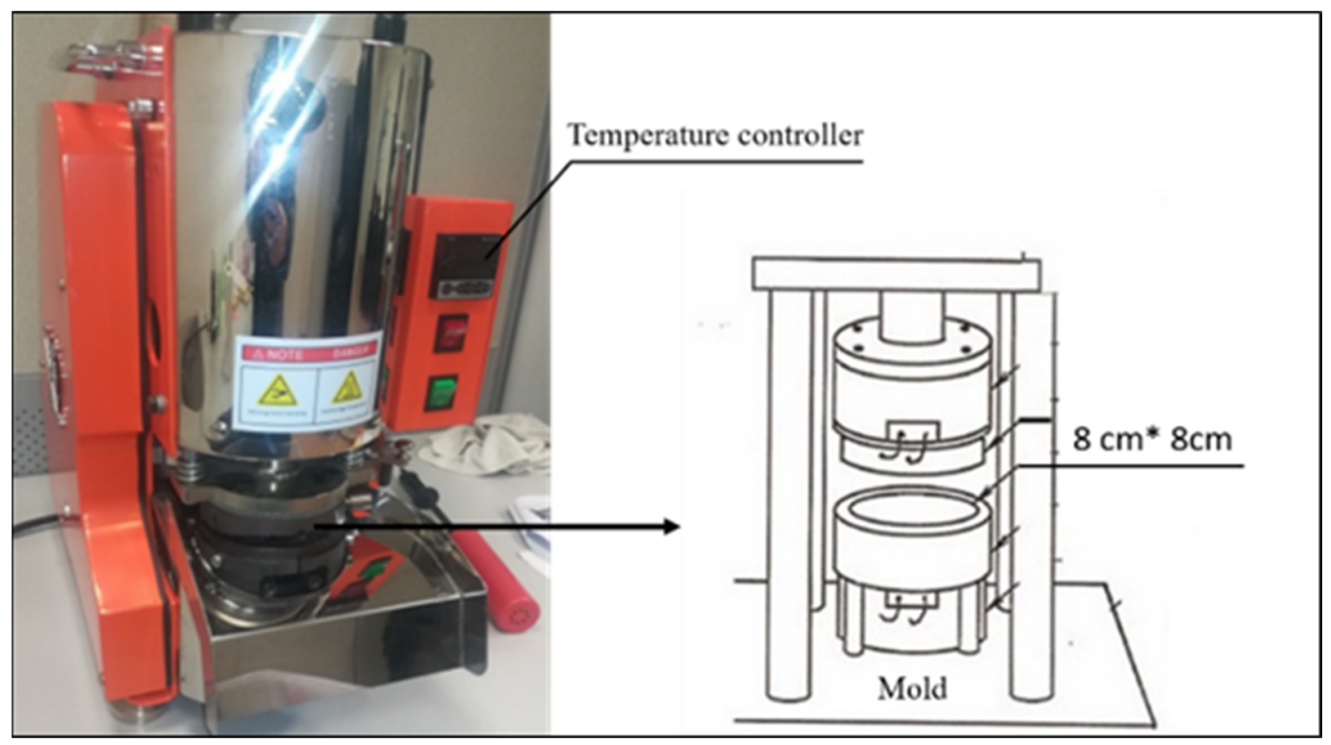

Figure 4. Experimental setup used into produce the proposed new bio-insulation material.

\subsection{Fire Reaction Test}

Analyzing the behavior of thermal insulation in case of fire is very important. For this purpose, the flammability test UL94 V was performed in the present study, as this small-scale fire test was initially developed to examine the ignition and flame spread for different types of plastics and bulk materials [24]. A sample of $8 \mathrm{~cm}$ length and $1 \mathrm{~cm}$ thickness was investigated using the experimental setup shown in Figure 5. 


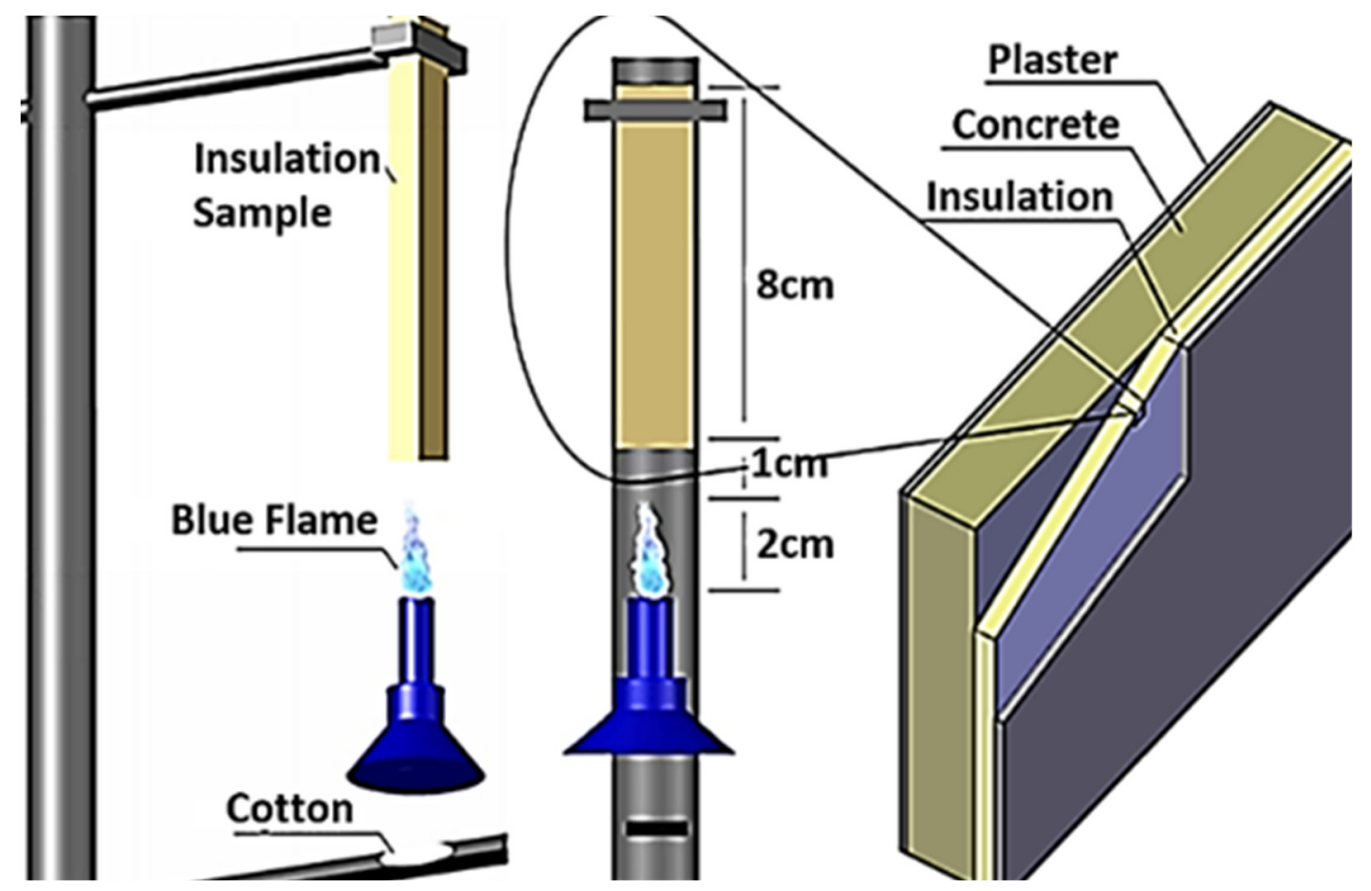

Figure 5. UL94 V experimental setup of flammability test for the puffed rice insulation sample.

\section{Results and Discussion}

\subsection{Screening Study}

Once the presoaked and dried rice grains were subjected to a high temperature and pressure, sudden evaporation transformed the starch that remained inside the grains from a hard to a rubbery state. When the heat and pressure were suddenly released from the mold, the grains rapidly expanded. A set of screening experiments was carried out to determine whether long- or short-grained rice was more suited for puffing and to establish the optimal values of other influential parameters. One factor at a time was tested in the screening step to determine the significant factors affecting sample thickness, sample shape, surface smoothness, and puffing ratio.

Our findings revealed that shorter grains exhibited greater puffing ability, while also yielding better results in terms of puffing ratio, sample thickness, circular shape, and surface smoothness. Thus, in the subsequent steps, short-grained rice was used in the material optimization, aiming to improve thermal conductivity and overall performance.

\subsection{Applicable Experimental Range of Sample Weight, Temperature, and Moisture Level}

As some samples burned when exposed to $280^{\circ} \mathrm{C}$, while the moisture ratio was too high for sufficient puffing to occur in others, or the sample shape was inconsistent due to the variations in the amount of raw material used (Figure 6), we eliminated these issues by restricting the temperature, moisture level, and sample weight to $260-270{ }^{\circ} \mathrm{C}, 12-16 \%$, and $15-17 \mathrm{~g}$, respectively. 


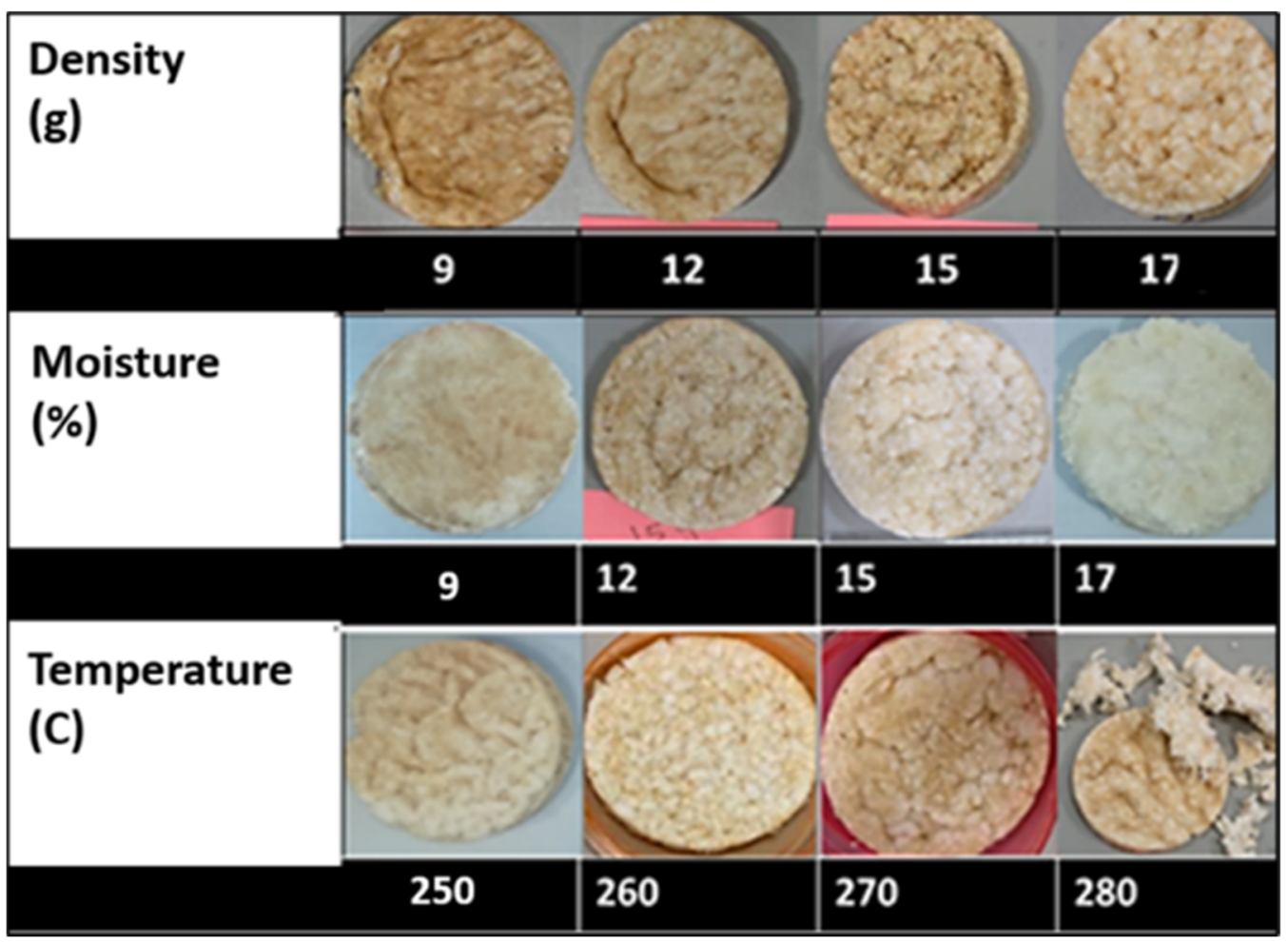

Figure 6. The produced insulation samples with different levels of moisture, density, and temperature.

\subsection{Thermal Conductivity Test}

The thermal conductivity of the proposed new "puffed rice insulation" sample was tested using the Fox 200 thermal conductivity device, as well as a low-density polystyrene as it is the insulation material commonly used in the UAE construction market. A dry sample of $8 \mathrm{~cm}$ in length and $1 \mathrm{~cm}$ in thickness was prepared to be investigated for both specimens. The Fox 200 device is an accurate instrument and well-suited to measuring slices with different thicknesses up to $0.025 \mathrm{~mm}$ according to ASTM C518 and ISO 8301. The Fox 200 device has an upper and lower thermal plate to hold the sample. The centers of both plates start to generate a heat flux at the beginning of the test. The thermal conductivity tests were performed at five different mean temperatures: 5, 15, 25, 35, and $45^{\circ} \mathrm{C}$. The daily average temperature ranges from $18{ }^{\circ} \mathrm{C}$ in January to around $35^{\circ} \mathrm{C}$ in August, which is within the used device minimum and maximum temperature range for each run, thereby providing rapid and accurate results. The thermal conductivity values measured at different temperatures for both insulation samples are reported in Table 2.

Table 2. The thermal conductivity values for puffed rice insulation and polystyrene insulation samples.

\begin{tabular}{ccc}
\hline \multirow{2}{*}{$\begin{array}{c}\text { Temperature } \\
{\left[{ }^{\circ} \mathrm{C}\right]}\end{array}$} & \multicolumn{2}{c}{ Thermal Conductivity W/(mK) } \\
\cline { 2 - 3 } & Bio-Insulation Material & Polystyrene \\
\hline 5 & 0.04156 & 0.03541 \\
\hline 15 & 0.04473 & 0.03790 \\
\hline 25 & 0.04672 & 0.03985 \\
\hline 35 & 0.04834 & 0.04187 \\
\hline 45 & 0.04971 & 0.04395 \\
\hline
\end{tabular}

The results show that, according to the thermal conductivity k-values, the newly developed bio-insulation material "puffed rice insulation" is suitable for use as insulation 
material, especially when compared with other commercially available alternatives, as shown in Figure 7.

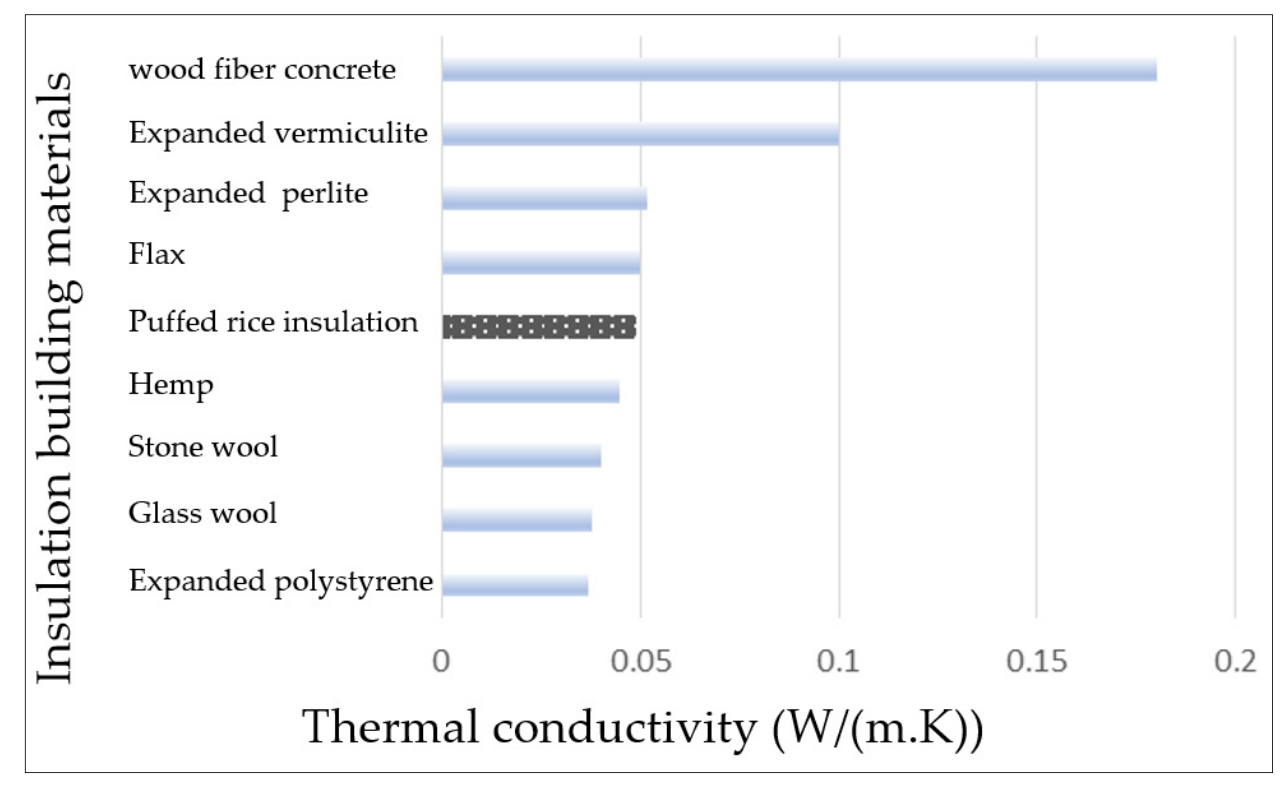

Figure 7. Thermal conductivity comparison between building insulation materials.

\subsection{Fire Reaction}

In the next step of the investigation, five puffed rice insulation samples that exhibited the best performance were subjected to the UL94 V fire reaction test. In selecting the test, it was important to perform more than just an evaluation of the specimens. U L94 V fire test evaluates the burning and afterglow times, as well as the dripping of the burning test specimen, and gives a visible indication of toxic gases released during the test. The results were indicative of $\mathrm{V} 1$ classification, as $\mathrm{t} 1+\mathrm{t} 2<250 \mathrm{~s}$ and $\mathrm{t} 2+\mathrm{t} 3<60 \mathrm{~s}$ were obtained for all five specimens. No after flame or afterglow extending up to the holding clamp and no burning drops were detected.

Figure 8 shows the phases that the puffed rice insulation samples underwent during the fire test. As explained previously, a blue flame for methane gas, indicates "the temperature is about $1960^{\circ} \mathrm{C}$, according to the flame color temperature chart", of $2 \mathrm{~cm}$ length was applied for a $10 \mathrm{~s}$ first round, while ensuring that it remained at a $1 \mathrm{~cm}$ distance from the specimen. Next, the sample was removed from the flame field to measure $t 1$, after which the flame was applied for a further $10 \mathrm{~s}$ second round to measure $\mathrm{t} 2$ and $\mathrm{t} 3$.

As can be seen from Figure 9, the fire never reached the holding clamp and no burning drops or toxic gases were detected in any of the five repeated tested samples, which used the same burning time of $20 \mathrm{~s}$ in total. On the other hand, the UL94 V fire test was applied to the polystyrene insulation material samples under the same conditions described earlier for the puffed rice insulation, to compare between the two insulation types and show the main differences. The tested polystyrene insulation material samples showed larger variations. The specimens burned completely in a shorter time than that recorded for the puffed rice insulation samples. After applying the flame to the polystyrene sample for $1 \mathrm{~s}$, it started to ignite very quickly and the gases began to emit dramatically, which led to the complete burning of the sample after $6 \mathrm{~s}$. 

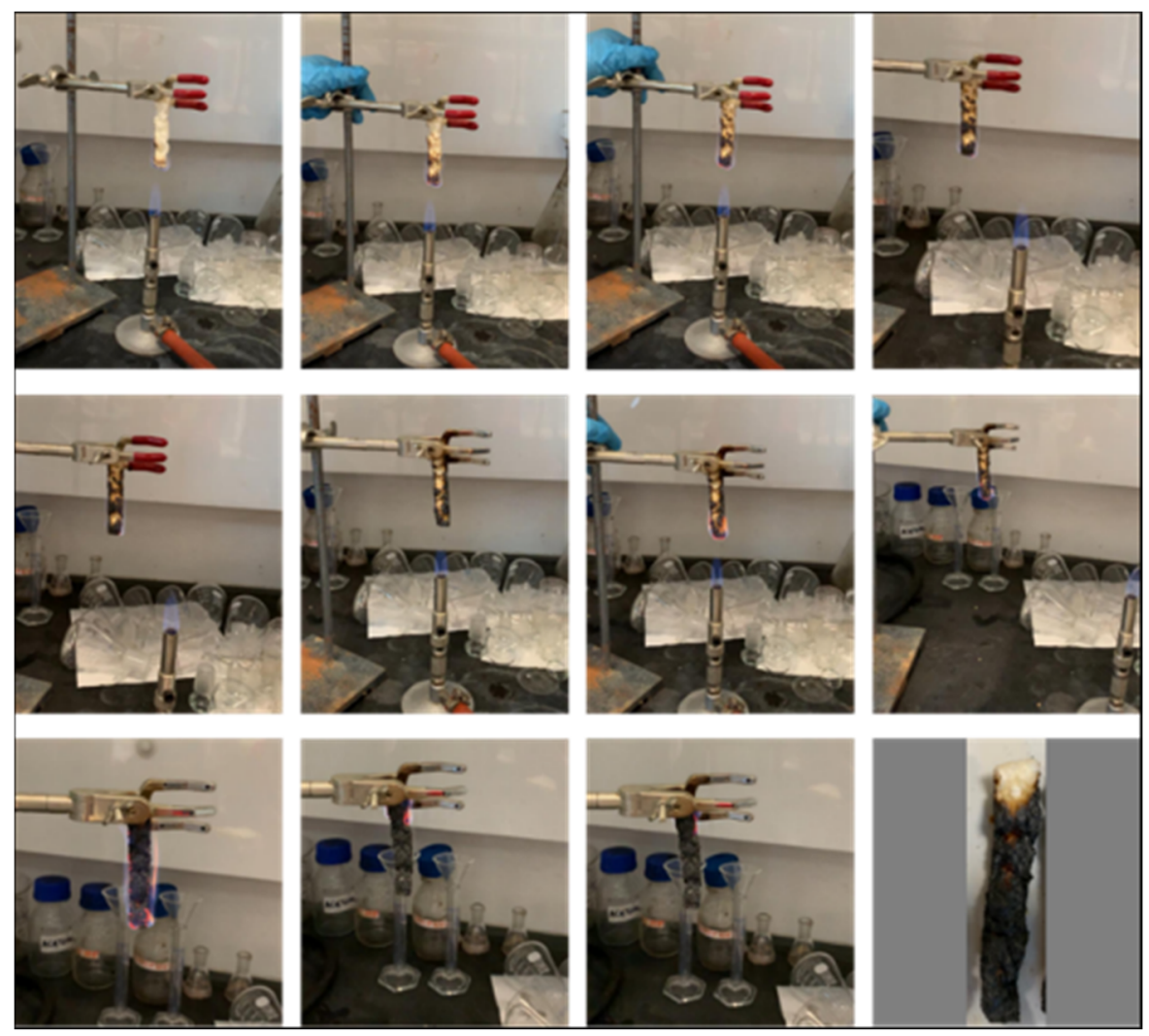

Figure 8. The puffed rice insulation sample phases under the UL94 V Fire test.

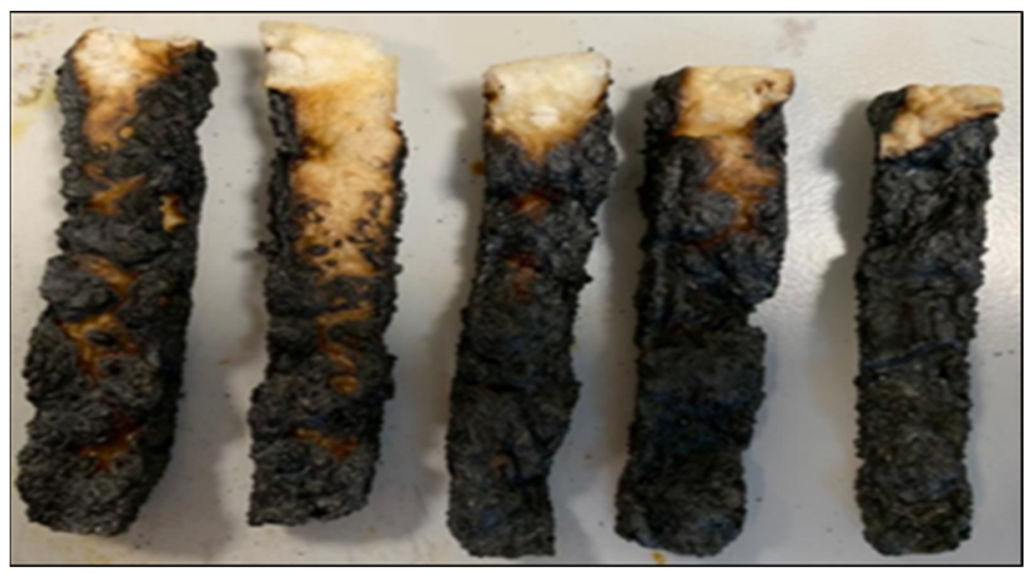

Figure 9. Insulation specimens after applying the UL94 V fire test.

Table 3 shows the differences observed between the puffed rice insulation material and polystyrene when subjected to a second fire inspection. For this test, two samples were exposed to a blue flame to measure the time required for the material to burn completely and to record any burning drops. The newly developed bio-insulation material exhibited superior stability and fewer dark gases were noticed, which was expected due to its organic origin. 
Table 3. Evaluation of the puffed rice and polystyrene insulation materials according to burning time, gas emission, and appearance of burning drops.

\begin{tabular}{cccc}
\hline Insulation Material & Burning Time (s) & Burning Drops & Material Vanishing \\
\hline Puffed rice & 20 & No & No \\
\hline Polystyrene & 6 & Yes & Yes \\
\hline
\end{tabular}

\section{Conclusions}

In this research, a bio-based thermal insulation material was developed using shortgrained puffed rice and was subjected to extensive tests to optimize its thermal conductivity. These assessments indicated that the most optimal thermal conductivity of the insulation material and the highest puffing ratio was attained at $12-15 \%$ moisture, $260-270{ }^{\circ} \mathrm{C}$ temperature, and 15-18 g sample weight. The thermal properties, including thermal conductivity, fire reaction, and thermal performance of samples obtained using these parameters were similar to those of common insulation materials. Specifically, the minimum thermal conductivity value was $0.04971 \mathrm{~W} / \mathrm{mK}$ and according to the UL94 V flammability test, the puffed rice insulation material exhibited good fire reaction (V1). Consequently, this bio-based thermal insulation material has considerable commercialization potential, as it is environmentally friendly, exhibits high thermal stability, produces no toxic gas emissions, and has thermal performance comparable to that of common insulation materials. These advantages make this newly developed material a strong competitor in the thermal insulation market.

\section{Future Work}

The findings yielded by this study could be expanded upon by obtaining additional thermophysical and mechanical data and conducting cost estimation analyses, as shown below:

- An insulation board of size typically used in construction $(1 \mathrm{~m} \times 1 \mathrm{~m})$ for instance could be evaluated under actual wall structure conditions.

- The environmental impact of the degradation of the rice insulation material composite, including humidity and thermal transmission, could be investigated.

- The mechanical properties of the sample, such as tensile strength, compressive strength, and shear strength, could be evaluated.

- The cost of large-scale production of the puffed rice insulation material needs to be estimated.

Author Contributions: Conceptualization, M.K., A.H., A.D.S. and S.A.; methodology, M.K. and A.D.S.; software, A.D.S.; validation, A.D.S.; formal analysis, M.K. and A.D.S.; investigation, A.D.S.; resources, A.D.S. and S.A.; data curation, A.D.S.; writing—original draft preparation, A.D.S.; writingreview and editing, M.K.; visualization, M.K. and A.D.S.; supervision, M.K. and A.H.; project administration, M.K. and A.H. All authors have read and agreed to the published version of the manuscript.

Funding: This research was funded by Research Center-Based Interdisciplinary, UAE University (Grant No. G00003230).

Institutional Review Board Statement: Not applicable.

Informed Consent Statement: Not applicable.

Data Availability Statement: Not applicable.

Conflicts of Interest: The authors declare no conflict of interest.

\section{References}

1. Dixon, G.; Abdel-Salam, T.; Kauffmann, P. Evaluation of the effectiveness of an energy efficiency program for new home construction in eastern North Carolina. Energy 2010, 35, 1491-1496. [CrossRef]

2. EIA. Annual Energy Outlook; U.S. Energy Information Administration: Washington, DC, USA, 2017.

3. IEA. World Energy Outlook; Clean Energy Ministerial: Paris, France, 2011. 
4. $\quad$ IEA. Clean Energy Progress Report; Clean Energy Ministerial: Paris, France, 2013.

5. $\quad$ Ong, H.C.; Mahlia, T.M.I.; Masjuki, H.H. Ren Sust. Energy Rev. 2011, 15, 639-647.

6. Patterson, M. What is energy efficiency?: Concepts, indicators and methodological issues. Energy Policy 1996, 24, 377-390. [CrossRef]

7. Dubai, E. How to Save on Energy Consumption. UAE. Retrieved 18 May 2020. Available online: https://www.energydubai com/energy-consumers/save-energy-consumption/ (accessed on 20 April 2021).

8. Berde, P.A.; Bhavani, R.G. Investigation for reducing energy consumption for a university campus in Dubai using automation. In Proceedings of the 2015 IEEE Recent Advances in Intelligent Computational Systems (RAICS), Trivandrum, India, 10-12 December 2015; pp. 358-363.

9. Majumder, A.; Canale, L.; Mastino, C.C.; Pacitto, A.; Frattolillo, A.; Dell'Isola, M. Thermal Characterization of Recycled Materials for Building Insulation. Energies 2021, 14, 3564. [CrossRef]

10. Al-Homoud, M.S. Performance characteristics and practical applications of common building thermal insulation materials. Build. Environ. 2005, 40, 353-366. [CrossRef]

11. Domínguez-Muñoz, F.; Anderson, B.; Cejudo-López, J.M.; Carrillo-Andrés, A. Uncertainty in the thermal conductivity of insulation materials. Energy Build. 2010, 42, 2159-2168. [CrossRef]

12. Pinto, J.; Paiva, A.; Varum, H.; Costa, A.; Cruz, D.; Pereira, S.; Fernandes, L.; Tavares, P.; Agarwal, J. Corn's cob as a potential ecological thermal insulation material. Energy Build. 2011, 43, 1985-1990. [CrossRef]

13. Palumbo, M.; Lacasta, A.M.; Navarro, A.; Giraldo, M.P.; Lesar, B. Improvement of fire reaction and mould growth resistance of a new bio-based thermal insulation material. Constr. Build. Mater. 2017, 139, 531-539. [CrossRef]

14. Schiavoni, S.; D'Alessandro, F.; Bianchi, F.; Asdrubali, F. Insulation materials for the building sector: A review and comparative analysis. Renew. Sustain. Energy Rev. 2016, 62, 988-1011. [CrossRef]

15. Collet, F.; Prétot, S. Thermal conductivity of hemp concretes: Variation with formulation, density and water content. Constr. Build. Mater. 2014, 65, 612-619. [CrossRef]

16. Stamyr, K.; Thelander, G.; Ernstgård, L.; Ahlner, J.; Johanson, G. Swedish forensic data 1992-2009 suggest hydrogen cyanide as an important cause of death in fire victims. Inhal. Toxicol. 2012, 24, 194-199. [CrossRef] [PubMed]

17. European Committee for Standardization. Fire Classification of Construction Products and Building Elements-Part 1: Classification Using Data from Reaction to Fire Tests; British Standards Institution: London, UK, 2007.

18. Asdrubali, F.; D'Alessandro, F.; Schiavoni, S. A review of unconventional sustainable building insulation materials. Sustain. Mater. Technol. 2015, 4, 1-17. [CrossRef]

19. Dikmen, N.; Ozkan, S.T.E. Unconventional insulation materials. In Insulation Materials in Contexts of Sustainability; IntechOpen: London, UK, 2016. [CrossRef]

20. Kuo, L. Wasted Rice in Asia Emits over 600 Million Tonnes of Greenhouse Gases a Year. 2013. Available online: https:/ qz.com/ 123456/wasted-rice-in-asia-emits-over-600-million-tonnes-of-greenhouse-gases-a-year/ (accessed on 12 September 2013).

21. Chandrasekhar, P.R.; Chattopadhyay, P.K. Studies on microstructural changes of parboiled andpuffed rice. J. Food Process. Preserv. 1990, 14, 27-37. [CrossRef]

22. Sumnu, G.; Datta, A.K.; Sahin, S.; Keskin, S.O.; Rakesh, V. Transport and related properties of breads baked using various heating modes. J. Food Eng. 2007, 78, 1382-1387. [CrossRef]

23. Kaláb, M.; A Bowl of Rice and SEM. A Bowl of Rice and SEM. Infocus Mag.-Proc. R. Microsc. Soc. UK 2018, 1, 13-36.

24. Laoutid, F.; Bonnaud, L.; Alexandre, M.; Lopez-Cuesta, J.-M.; Dubois, P. New prospects in flame retardant polymer materials: From fundamentals to nanocomposites. Mater. Sci. Eng. R Rep. 2009, 63, 100-125. [CrossRef] 